\title{
Health promotion and psychological interventions for adolescent and young adult cancer survivors: a systematic literature review
}

Authors:

Natalie Katrina Bradford $*^{a}$, Raymond Javan Chan ${ }^{b, c}$

${ }^{a}$ Queensland Youth Cancer Services, Children Health Queensland, Brisbane, Australia

${ }^{b}$ School of Nursing and Institute of Health and Biomedical Innovation, Queensland University of Technology, Kelvin Grove, Queensland, Australia

${ }^{c}$ Cancer Nursing Professorial Precinct, Royal Brisbane and Women's Hospital, Herston, Queensland, Australia

*Correspondence to:

Dr Natalie Bradford,

Address: Level 5, Centre for Children's Health Research

62 Graham St, South Brisbane, 4101, Queensland, Australia

Phone: t: +61 730697468

Email address: Natalie.Bradford@health.qld.gov.au 
Health promotion and psychological interventions for adolescent and young adult cancer survivors: a systematic literature review 


\begin{abstract}
Background

The effects of cancer and treatment have severe and long lasting negative impacts on quality of life. Adolescents and Young Adults (AYA) have high survival rates but may not reach their full life potential because of these consequences. This review aims to identify, appraise and synthesise the effects of health promotion and psychological interventions for AYA after cancer treatment.
\end{abstract}

\title{
Methods
}

The review was undertaken using the preferred reporting items for systematic reviews and metaanalyses guidelines. Included studies were identified though a range of electronic databases through to May 2016. Studies were critically appraised using the Cochrane Risk of Bias tool.

\section{Results}

Seventeen studies, comprising a total of 2314 participants aged 13-39 years were included in this review. Participants in 15 studies were survivors of childhood cancer, with only two studies specifically recruiting survivors of cancer diagnosed during young adulthood. Ten studies were randomised controlled trials (RCTs); the remaining seven were before and after studies. The quality of studies was variable across all appraised domains; risk of bias was evident in regards to recruitment, measures of exposure and outcomes, confounding factors, attrition and lost-to follow-up. Studies evaluated a range of health promotion and psychological interventions to improve health related and process outcomes. Eleven studies reported modest positive outcomes, with psychological and physical activity interventions achieving greater success compared to general health promotion interventions.

\section{Conclusion}

This review highlights the lack of high-quality studies for optimising the health and well-being of AYA cancer survivors. No conclusive evidence favouring specific interventions were identified, 
although recommendations for future studies are made. Interventions delivered face-to-face and those that facilitate peer-to-peer support hold promise. Harnessing social media and technology to deliver interventions is likely to increase and these modes of delivery require further investigations.

\section{Keywords}

Adolescent and Young Adult; Cancer; Survivorship; Quality of life; Health and Well-being; Interventions 


\section{Introduction}

When active cancer treatment ends, patients describe feelings of contradiction and uncertainty about their future. $[1,2]$ Survivorship is understood to be a process of living with, through and beyond a cancer diagnosis, and as such has been described as a process of liminality, or a series of passages one takes to move through life events.[3] The concept of liminality proposes the transitional phase between one passage and another- the liminal phase - is often associated with feelings of ambiguity and paradox, when one doesn't quite fit or belong to any group.[4] Thus patients who have completed treatment for cancer, may not return to their previous sense of self, nor quite see themselves as 'survivors' as the threat of the return of cancer remains prominent.

Adolescence and Young Adults (AYAs) who have completed treatment for cancer face additional challenges to their sense of self. The time period between childhood and adulthood, recognised variably as the years between 10-39,[5] is when important cognitive, psychosocial and emotional developments occur. Cognitively, the ability to think abstractly and to reflect upon ones one thoughts and ideas ensue. [6] Psychosocially, a sense of personal identity develops, peer group relationships become increasingly important along with independence from parents. [7] Emotionally, this time period can be characterised by feelings of anxiety and self-consciousness, and is recognised as a time when there may be less control over emotions. [8] The impact of a cancer diagnosis and subsequent treatment during this period is understood to pose further challenges to the developing individual. AYA patients report altered sense of identity; changed relationships; challenges to body image and sexuality; impacts on education and employment with financial consequences; concerns about cancer recurrence; a pre-occupation with death and dying, and generally a less positive outlook on life. $[9,10]$

In Australia, disease-free five-year survival for AYAs aged 15-29 years has reached 88\%. [11] However, survivors are at risk of long-term health problems; up to $70 \%$ report at least one chronic health problem and up to $40 \%$ have severe problems and need ongoing medical intervention or surveillance. This is significantly different to AYAs with no history of cancer. Compared with their counterparts, AYA cancer survivors have more disability, chronic disease, and poorer mental and physical health. [12]

Evidence suggest there are modifiable risk behaviours, such as diet, smoking and alcohol intake, that are associated with this increased incidence of chronic health conditions and also for secondary malignancies.[12] As AYAs represent the future workforce, prospective parents and community members of a society, investing in 
their health needs is warranted. Indeed not meeting their health needs is likely to increase costs to the health and social welfare systems.[13] With increasing pressures on health budgets, there is a need to ensure interventions to address health needs are both effective and economical. Interventions in this population may be broadly categorised into those that promote health or those that address psychological issues. Health promotion interventions are defined as combinations of educational, organisational or environmental actions that support behaviour modification conducive to health.[14] Psychological interventions are defined as evidence-based formalised strategies that aim to alter self-re-informing processes and improve individuals outcomes.[15]

A number of reviews have synthesised either health promotion or psychological interventions for AYAs with cancer. A review examining the long-term and life-long psychological impacts of cancer in this population reported complex, challenging and nuanced problems and highlighted the need for specific interventions targeting finances, relationships, education, goals, body image and physical well-being [16]. Walker et al. undertook a critical review of psychosocial interventions finding the availability of psychosocial interventions were increasing and although higher quality studies are needed, the results suggest interventions are beneficial.[17] Pugh et al completed a systematic review of health behaviour change interventions and concluded further work is required to evaluate how best to promote health change behaviour in young people.[18] Wurz et al completed a systematic review of two controlled trials regarding the effects of physical activity on health related quality of life for adolescent cancer survivors; the authors found physical activity was safe, feasible and showed promise for improving health and quality of life.[19] To date, no systematic review has collated high level evidence (i.e. randomised controlled trials, controlled trials) of all health behaviour and psychological interventions for AYAs with cancer to identify the attributes associated with positive changes. Therefore, the aim of this systematic review was to identify, appraise and synthesize the effects and attributes of health behaviour and psychological interventions on health-related or process outcomes for AYA cancer survivors. Health related outcomes of interest included quality of life, symptom burden, unmet needs, rates of hospitalisation, or screening for new cancers. Process outcomes of interest included patient behavioural uptake, quality of care, training and education, satisfaction, costs and resource utilisation. 


\section{Methods}

Randomised controlled trials (RCTs); quasi RCTs; controlled before and after studies, and before and after studies that examined the effects of health promotion and psychological interventions for AYA cancer survivors were included. The protocol for this review was registered with PROSPERO ref 42016036470.

\section{Search Strategy}

The search terms were devised by the study authors in consultation with a medical research librarian. Searches included combinations of the terms: (physical interventions, psychological intervention, physical therapy, psychological therapy, physical treatment, psychological treatment) AND (follow up, end of treatment, survivorship, cancer survivor) AND (cancer, neoplasm, oncology) AND (adolescent, teenager, young adult, youth, minor) AND (quality of life, value of life, quality assurance, distress, anxiety, outcome assessment, health outcome, healthcare economics). Databases searched included: Medline; CINAHL; Web of Science; PsycINFO; EMBASE and Cochrane CENTRAL. These databases were searched up to May 2016. Authors of studies were contacted for further information if required. Hand searching of referenced articles was also undertaken. Searches were restricted to humans and the English language. Studies were excluded if full text were not available.

\section{Selection criteria}

The population of interest for this review were adolescents and young adults, aged 15-25 years, who have completed treatment for cancer. We aimed to include studies where participants were potentially diagnosed during adolescents or young adulthood. The age range of 15 to 25 years was chosen as in Australia, AYA cancer services are limited to this group. Studies with participants beyond this age range were included if their study population included a substantial (25\%) proportion of participants in this age range at the time of cancer diagnosis, or time of study. Articles were included if they reported any health promotion or psychological intervention or therapy during survivorship. All studies were required to have a comparator group or comparator measure. Outcomes of interests included any health-related outcomes (e.g. quality of life, symptom burden, unmet needs, rates of hospitalisation, screening for new cancers) or process outcomes (e.g. patient behavioural uptake; quality of care; training and education; satisfaction; costs and resource utilisation). Secondary outcomes included attributes of, and resources required, for the intervention, as well as benefits and shortfalls. The study 
setting could be primary, secondary or tertiary level health facilities, or interventions delivered in community settings.

\section{Data collection}

All titles and abstracts were screened for eligibility independently by both authors (NB, RC). Full text articles were reviewed independently by the same two authors against the inclusion and exclusion criteria. Discrepancies were resolved by discussion. A summary of the selection process is presented in Figure 1. Data extraction were completed using pre-defined data extraction forms and included details regarding: authors; publication year; country; study design; study aim; characteristics of participants; content and intensity of the interventions; sample size; response rate; outcome measures; resources required; findings, and the level of evidence of the study (see Box 1). [20] The quality of all studies was appraised using the Cochrane Risk of Bias tool. As per the Cochrane handbook, non-randomised trials were also appraised for risk of selection bias and other potential confounding factors.[15] The Risk of Bias tool examines seven categories relating to the design, conduct, analysis and presentation of factors that may cause the effect of an intervention to be over or underestimated. Each category is rated as having either low, high or unclear levels of bias. Both study authors independently rated studies and reached consensus through discussion. The quality assessment did not influence inclusion of studies; all identified studies were included in the narrative synthesis regardless of their rating. [21] Data from each study were summarized and synthesized where possible. Where statistically significant findings were reported for continuous variables, the mean difference (MD) from baseline to last follow-up was calculated with $95 \%$ confidence intervals. For categorical data, odds ratios (OR), percentage comparisons, and simple descriptive statistics were used to summarize the data.

\section{Results}

\section{Overview of included studies}

A total of 17 articles were included in this review. Characteristics of included studies are summarized in Table

1. Authors of two included studies were contacted and provided further information regarding participant ages.[22, 23] Of the 17 included studies, 24\% $(n=4)$ [24-27] were before and after studies, 18\% ( $n=3)$ [28-30] were controlled before and after studies, and 59\% $(n=10)[22,23,31-37]$ were RCTs comprising a total of 2314 
participants across all studies. The smallest study recruited 10 participants and the largest 796 . In 15 studies, participants were survivors of cancers diagnosed during childhood or adolescence. Two studies specifically focussed on recruiting survivors diagnosed during young adulthood. [37, 38] Ages of participants ranged 13-39 years, and mean time since diagnosis ranged 1.9-21.8 years. All studies included both males $(\mathrm{N}=1087,49 \%)$ and females $(\mathrm{N}=1227,53 \%)$. Caucasians were the most represented ethnic group across all studies, with the larger studies also recruiting small proportions of African Americans, Hispanic and Asian participants. All studies were conducted in developed nations; 11 were undertaken in the USA [22-24, 28, 31-37], one in Canada [38], two in the UK [25, 29], and three in Northern European countries [26, 27, 30]. Cancer survivor diagnoses commonly included acute lymphoblastic leukaemia as well as other childhood cancers and those seen in adolescence and young adulthood. Some studies excluded patients with brain tumours due to potential cognitive impairment.

Over half $(n=10,58 \%)$ of the studies included in the review were Level II evidence from RCTs, potentially contributing high levels of evidence. However, there was significant variability in the quality appraisal of all studies; risk of bias was evident across multiple domains, and in particular with regards to recruitment, measures of exposure, confounding factors, attrition and follow up (see Table 2).

\section{Target outcomes of included studies}

The aims of studies were to examine feasibility of the intervention $[24,25,33,37]$, to establish the efficacy or impact of the intervention on outcomes [22, 23, 26-28, 30-32, 34, 36-38], and two studies were undertaken to confirm the results of earlier pilot studies [29, 35]. Studies were categorised into two groups depending on the primary objective of their intervention: health promotion or psychological well-being. Outcomes of interventions included:

- health related outcomes, e.g. quality of life, anxiety and depression, fatigue, perceived vulnerability and motivation

- $\quad$ process outcomes, e.g. behavioural uptake of physical activity or health practices, satisfaction and feasibility

\section{Attributes of studies}


Most interventions were delivered face-to-face in individual sessions ( $\mathrm{n}=9,53 \%)[22,25,28-32,34,35]$, with use of telephone and workbooks as 'boosters'. The telephone $(n=3,18 \%)[26,33,36]$ and internet $(n=3,18 \%)$ $[23,27,37]$ were also commonly used as the primary mode for delivering the interventions. One study used group sessions with peers, [24] and one population based study mailed guidebooks with worksheets to participants.[38] Table 2 summarises all studies by intervention group, attributes and mode of intervention delivery, outcome measures and summary effects of interventions. Response rates for studies varied widely; some studies contacted hundreds of potential participants only to recruit a relatively small number to the study.[30, 31, 38] Response rates ranged from 11- 87\% with retention to studies also varying widely between $59-100 \%$.

\section{Outcomes}

\section{Health Promotion Interventions}

Physical Activity

Five studies $[24,26,30,37,38]$ examined interventions to promote physical activity and all reported positive outcomes. One study evaluated a home training program finding improved physical fitness and reduced peak oxygen uptake in 17 participants.[26] Similarly, group based exercise sessions improved physical activity and fitness for a small group of 10 participants [24], and counselling sessions with use of a pedometer decreased in fatigue in a study with 46 participants.[30] A study using Facebook to deliver cognitive theory-based intervention to 86 participants found significant increases in physical activity in both the control and intervention groups, with greater improvements seen in the intervention arm.[37] A printed guidebook targeting young adult cancer survivors was found to be superior to existing guidelines for a subset of 96 participants reporting less than 300 minutes/week of exercise.[38] All five studies reported the interventions were feasible and safe, with three studies reporting the interventions were economical requiring no special facilities. [30, 26, 37] Effect sizes were modest, with wide confidence intervals reducing precision; results were suggestive rather than conclusive in their findings.

\section{Other health promotion interventions}


There were six studies reporting effects of a range of interventions to improve diet, bone health, tobacco use, psychosexual development and knowledge of cancer risk factors. [22, 23, 29, 31, 32, 34] Unlike the reported success of physical activity, there were only two studies that reported success with these interventions [31, 34]

One of these successful studies was an RCT that tested the effect of educational sessions to enhance psychosexual development. While the study found significant improvement in cancer related sexual knowledge, confidence, body image and a decrease in emotion distress, the authors acknowledge that the sample is most likely biased with counselling being more attractive to those with problems. Of the several hundred participants contacted, only 24 were ultimately recruited. [31] The other study found skill building exercises were effective at improving dietary intake. The authors found their methodology was well received, relevant and understandable and that findings are potentially important for the long term health for AYA cancer survivors. [34]. Again, the precision of effect sizes was reduced by wide confidence interval, some encompassing the null; results were suggestive rather than conclusive of positive effects.

The other studies in this group attributed the lack of success of their interventions to a variety of factors: an information package aimed at improving readiness to change and self-efficacy was troubled by lost to follow-up participants[29]; a one month counselling interventions to promote health-protective behaviours was deemed not intensive enough [32]; a web portal with personalised information was found to in-effective with improving knowledge of risks of cancer treatment- few participants actually logged on and used the portal [23], and a single session with educational counselling (with periodic telephone re-enforcement) regarding the risks of smoking had no effect on participants who smoked. [22]

\section{Psychological interventions}

Six studies reported the results of psychological interventions and five found sustained positive effects on outcomes including anxiety or depression, decision making, motivation and health practices. [25, 27, 33, 28, 36] Metacognitive therapy was used in one study [25] with positive effects in reducing anxiety, depression and posttraumatic symptoms in AYAs experiencing clinically significant distress related to their cancer. Internet-based cognitive behavioural therapy was used in another study [27], and found significant reduction in anxiety with clinical improvements that were sustained in those who completed and were followed up. However this study 
had a large number of withdrawals and lost-to-follow ups; the authors concluded strategies were needed to better engage with younger participants for online interventions. [27] Hollen et al tested the effect of a decision making workshop on risk reduction behaviours and found short term effects for smoking. The authors acknowledge that participants may have self-selected and have been more motivated [28]. The study was repeated with a larger, more diverse sample, and found some immediate change in substance use motivation. Feasibility of the program was established, however the overall effects were modest and not sustained at 12 month follow up.[35] The telephone was used to deliver coping skills training to reduce anxiety and uncertainty in one study [33] and found modest improvements; there were significant delays with obtaining outcome measures that may have biased results. The most significant results were found in Emmons et al study where counsellors, who were survivors of childhood cancer themselves, provided motivational interviewing to cease smoking. [36] The intervention improved the likelihood of efforts to cease smoking. However, in this study, the intervention arm also had access to free nicotine patches whereas the control arm needed to purchase their own. This may account for the higher quit rate in the intervention arm. Aside from the findings in Emmons et al, the other four studies reporting positive effects from their interventions reported modest effect sizes, again with wide confidence intervals reducing the precision of the effect; results were largely suggestive rather than conclusive.

\section{Discussion}

The findings of this review highlight the lack of robust evidence to support interventions to promote health and well-being for AYAs after cancer treatment. While 11 of the 17 included studies reported positive effects of their intervention on outcomes, studies were all beset with methodological weaknesses that diminish the certainty of the effects of interventions. Additionally, given the heterogeneity of the included studies, it is not possible to draw firm conclusions regarding the most effective attributes of interventions, and few studies reported the resources required. The majority of interventions deemed effective were delivered in individual face-to-face sessions with a clinician and supplemented with workbooks or phone calls during the study period. One study found Facebook to be an acceptable, feasible and effective platform to promote physical activity.[37] This study found both groups participated in peer support chat on group walls and had improved levels of 
physical activity, with the group that received the more intensive and directed cognitive theory-based intervention reporting higher increases of physical activity. Of interest however, is the otherwise lack of success with Internet based interventions; two other studies that used this strategy both had large numbers of withdrawals, lost to follow ups, or participants that did not even log on to the intervention.[27, 23] This is somewhat counter-intuitive as AYAs are generally high users of the Internet and technology based applications. This phenomenon is not limited to the studies included in this review; other studies have also found the Internet not useful for delivering interventions to young survivors.[39, 40] It is possible some young people view the Internet as a personal space where interactions with clinicians are not welcome. Conversely however, in other studies of cancer survivors aged to 39 years the Internet has been found useful. Physical activity was examined in two RCTs by Rabin et al. One study used a website designed to promote activity in sedentary adults that was adapted for young adult cancer survivors; the study demonstrated improvement in activity and participants reported high satisfaction with using the website. [41] A second study assessed a 12 week home-based program that included an online forum to connect with peers and found significant increases in physical activity and fitness as well as high satisfaction rates.[42] Further research is needed to understand the potential of harnessing the Internet to deliver interventions for this population.

It is well recognised cancer and cancer treatment has an immense psychological and physical impact on young people. The numbers of AYA surviving cancer treatment are exponentially increasing, and as young people, they have the most years to live with the consequences of cancer. Identifying and understanding interventions that improve outcomes of AYAs after cancer treatment should therefore be a priority for researchers. The paucity of evidence available to support AYAs after cancer treatment highlights the lack of research in this area. This is not surprising as relatively little attention has been paid to the specific needs of this population compared with that of children of older adults with cancer.[43] In fact, the vast majority of studies included in this review recruited participants who were survivors of childhood cancers, only two studies focussed solely on participants whose cancer was diagnosed during young adulthood. This is an area that requires further attention; it is highly likely the needs of a childhood cancer survivor differ significantly to that of one diagnosed during adolescence or young adulthood.[16] Additionally, it is important to identify strategies to engage this population in research and interventions that improve health and well-being. 
If we consider the AYAs experience of cancer, and reflect upon the liminal processes that occur through the transition from healthy individual, a cancer diagnosis, cancer treatment and end of treatment, we can appreciate that the passage is turbulent. While a focus on the treatment is necessary for survival, there is also a need to consider what life beyond treatment will look like. Much like palliative care is advocated to be considered at diagnosis with certain cancers [44], so too should we consider survivorship at the beginning of treatment or soon after diagnosis? It is clear that survivorship issues such as fertility must be considered early in the disease trajectory. However, the lack of consensus regarding when survivorship care should commence requires further investigation to establish, from both the patient and clinicians perspectives, the optimal time to plan for life beyond cancer treatment.[45] Additionally, to provide such care over time, the capacity for cancer programs to deliver services must be considered. [46]

Balancing the finite healthcare resources with the needs of AYA cancer survivors needs to occur in a way that will maximise the benefits to patients and provide value to health system. Value based healthcare is increasingly important and future research should take into account resources and cost benefits of interventions to patients, the healthcare system and the wider community.

The studies included in this review were categorised into health promotion and psychological groups by their interventions. Studies in the health promotion group focussed on promoting health and well-being to potentially prevent or minimise risks of developing secondary cancers or late effects of cancer treatment. Studies in this group typically aimed to encourage healthy lifestyles through diet, exercise and risk reduction behaviours, by fostering an understanding of the risks of sedentary lifestyles, smoking, alcohol and diet. While these studies focused on improving the AYAs awareness, self-efficacy and competence with decision making, they did not typically address actual ill health, or late effects associated with after cancer treatment. Similarly in the psychological group most studies focussed on interventions to promote health behaviours for a healthy lifestyle. There were only two studies in this group recruited patients with clinically significant distress that examined interventions for psychological support. [25, 27] One could argue resources and research efforts should focus on identified problems as well as preventative measures.

Our review has a number of strengths; we have collated the highest level of evidence available for health promotion and psychological interventions in this population group and provided and assessment of the current 
state of the evidence. We conformed to established principles for the conduct of this review [47] and identified a number of key areas that warrant further investigation. More studies are required with participants diagnosed during adolescence and young adulthood; understanding how to engage this population group is important. Given it is well documented that AYAs following cancer treatment are burdened with long-term consequences of cancer treatment [16], the lack of robust research to inform how best to meet the needs of patients with clinical problems post-treatment is concerning. While late effects may be managed by a medical treating team, the undesirable psychological effects such as changed sense of identity, body image, cancer recurrence concerns and pre-occupation with death and dying, and poorer outlook on life appear to be largely neglected.

Our study has notable limitations. Only a small number of studies met our eligibility criteria. Our focus on participants aged 15-25 years means we have not included studies of participants aged to 39 years who are considered young adults in other nations. However, for nations where funding of services is limited to those aged 15-25 years, this review provides important information regarding the feasibility and effects of interventions. There are few studies in our review that include minority groups from different cultural backgrounds; AYAs in these groups are underrepresented in studies and there is a paucity of evidence to inform their health needs after cancer treatment. Whilst we sought to include studies providing high level evidence, many of the included studies had small sample sizes, biases and short follow-up duration. Variations in study methodologies, focus of interventions, outcome measures and study quality meant we were not able to conclusively identify attributes of studies that were effective.

\section{Conclusion}

This review identified interventions focussed on supporting AYA cancer survivors is a developing area; the included studies were generally small with methodological limitations that reduce generalizability of findings and preclude the ability to make conclusive recommendations. There is a strong need to undertake studies for patients who are diagnosed during adolescence and young adulthood rather than survivors of childhood cancer. High quality, well powered RCTs incorporating cost-effectiveness analysis should be conducted in this population, with the priority given to interventions that hold promise. Interventions delivered face-to-face and those that facilitate peer-to-peer support have potential to achieve positive outcomes; harnessing social media 
and technology to deliver interventions is likely to increase and these modes of delivery require further investigations.

\section{Conflict of interest statement}

None declared

\section{Acknowledgments}

This work was supported by the Queensland Youth Cancer Service. Australian Youth Cancer Services receive federal funding through CanTeen as well as state and territory government funding, and provide specialist, ageappropriate treatment and support for young cancer patients aged $15-25$ years.

\section{References}

1. Mckenzie SE, Curle C. 'The end of treatment is not the end': parents' experiences of their child's transition from treatment for childhood cancer. Psycho-Oncology. 2012;21(6):647-54.

2. Kazak AE, DeRosa BW, Schwartz LA, Hobbie W, Carlson C, Ittenbach RF et al. Psychological outcomes and health beliefs in adolescent and young adult survivors of childhood cancer and controls. Journal of clinical oncology. 2010;28(12):2002-7.

3. Blows E, Bird L, Seymour J, Cox K. Liminality as a framework for understanding the experience of cancer survivorship: a literature review. Journal of advanced nursing. 2012;68(10):2155-64.

4. Turner V. Chapter III: Variations on a Theme of Liminality. Secular ritual, Assen: Gorcum. 1977:36-52.

5. Geiger AM, Castellino SM. Delineating the age ranges used to define adolescents and young adults. Journal of Clinical Oncology. 2011;29(16):e492-e3.

6. Piaget J, Inhelder B, Piaget J. The growth of logical thinking from childhood to adolescence: An essay on the construction of formal operational structures. Routledge; 2013.

7. Erikson EH. Childhood and society (Rev. ed.). New York: Norton; 1963.

8. Buchanan CM, Eccles JS, Becker JB. Are adolescents the victims of raging hormones? Evidence for activational effects of hormones on moods and behavior at adolescence. Psychological bulletin. 1992;111(1):62.

9. Bellizzi KM, Smith A, Schmidt S, Keegan TH, Zebrack B, Lynch CF et al. Positive and negative psychosocial impact of being diagnosed with cancer as an adolescent or young adult. Cancer. 2012;118(20):5155-62.

10. NHS Department of Health. Quality of life of Cancer Survivors in England. London2012.

11. AIHW. Cancer in adolescents and young adults in Australia. Cancer series no. 62. Cat. no. CAN 59. . Canberra: AIHW2011 Viewed 14 September 2016.

12. Tai E, Buchanan N, Townsend J, Fairley T, Moore A, Richardson LC. Health status of adolescent and young adult cancer survivors. Cancer. 2012;118(19):4884-91.

13. Ekwueme DU, Yabroff KR, Guy Jr GP, Banegas MP, de Moor JS, Li C et al. Medical costs and productivity losses of cancer survivors-United States, 2008-2011. MMWR Morb Mortal Wkly Rep. 2014;63(23):505-10.

14. Eldredge LKB, Markham CM, Kok G, Ruiter RA, Parcel GS. Planning health promotion programs: an intervention mapping approach. John Wiley \& Sons; 2016.

15. Walton GM. The new science of wise psychological interventions. Current Directions in Psychological Science. 2014;23(1):73-82. 
16. Barnett M, McDonnell G, DeRosa A, Schuler T, Philip E, Peterson L et al. Psychosocial outcomes and interventions among cancer survivors diagnosed during adolescence and young adulthood (AYA): a systematic review. Journal of Cancer Survivorship. 2016:1-18.

17. Walker E, Martins A, Aldiss S, Gibson F, Taylor RM. Psychosocial interventions for adolescents and young adults diagnosed with cancer during adolescence: a critical review. Journal of Adolescent and Young Adult Oncology. 2016;5(4):310-21.

18. Pugh G, Gravestock HL, Hough RE, King WM, Wardle J, Fisher A. Health behavior change interventions for teenage and young adult cancer survivors: a systematic review. Journal of adolescent and young adult oncology. 2016;5(2):91-105.

19. Wurz A, Brunet J. The effects of physical activity on health and quality of life in adolescent cancer survivors: a systematic review. JMIR Cancer. 2016;2(1):e6.

20. National Health and Medical Research Council. NHMRC Evidence hierachy: designations of 'levels of evidence' NHMRC. 2009. https://www.health.qld.gov.au/healthpact/docs/gen-docs/lvl-of-evidence.pdf. Accessed 23.11.16 2016.

21. Collaboration TC. Cochrane Handbook for Systematic Reviews of Interventions: Version 5.1.0 [updated March 2011]. 2011.

22. Tyc VL, Rai SN, Lensing S, Klosky JL, Stewart DB, Gattuso J. Intervention to reduce intentions to use tobacco among pediatric cancer survivors. Journal Of Clinical Oncology: Official Journal Of The American Society Of Clinical Oncology. 2003;21(7):1366-72.

23. Kunin-Batson A, Steele J, Mertens A, Neglia JP. A randomized controlled pilot trial of a web-based resource to improve cancer knowledge in adolescent and young adult survivors of childhood cancer. Psycho-Oncology. 2015:No Pagination Specified. doi:10.1002/pon.3956.

24. Keats MR, Culos-Reed SN. A community-based physical activity program for adolescents with cancer (Project TREK) - Program feasibility and preliminary findings. Journal of Pediatric Hematology Oncology. 2008;30(4):272-80. doi:10.1097/MPH.0b013e318162c476.

25. Fisher PL, McNicol K, Young B, Smith E, Salmon P. Alleviating Emotional Distress in Adolescent and Young Adult Cancer Survivors: An Open Trial of Metacognitive Therapy. Journal of Adolescent and Young Adult Oncology. 2015;4(2):64-9. doi:10.1089/jayao.2014.0046.

26. Järvelä LS, Kemppainen J, Niinikoski H, Hannukainen JC, Lähteenmäki PM, Kapanen J et al. Effects of a home-based exercise program on metabolic risk factors and fitness in long-term survivors of childhood acute lymphoblastic leukemia. Pediatric blood \& cancer. 2012;59(1):155-60.

27. Seitz DCM, Knaevelsrud C, Duran G, Waadt S, Loos S, Goldbeck L. Efficacy of an internet-based cognitive-behavioral intervention for long-term survivors of pediatric cancer: a pilot study. Supportive Care in Cancer. 2014;22(8):2075-83. doi:10.1007/s00520-014-2193-4.

28. Hollen PJ, Hobbie WL, Finley SM. Testing the effects of a decision-making and risk-reduction program for cancer-surviving adolescents. Oncology Nursing Forum. 1999;26(9):1475-86.

29. Eiser C, Hill JJ, Blacklay A. Surviving cancer: What does it mean for you? An evaluation of a clinic based intervention for survivors of childhood cancer. Psycho-Oncology. 2000;9(3):214-20. doi:10.1002/1099-1611(200005/06)9:3<214::AID-PON455>3.0.CO;2-O.

30. Blaauwbroek R, Bouma MJ, Tuinier W, Groenier KH, de Greef MHG, Meyboom-de Jong B et al. The effect of exercise counselling with feedback from a pedometer on fatigue in adult survivors of childhood cancer: a pilot study. Supportive Care In Cancer: Official Journal Of The Multinational Association Of Supportive Care In Cancer. 2009;17(8):1041-8. doi:10.1007/s00520-008-0533-y.

31. Canada AL, Schover LR, Li YS. A pilot intervention to enhance psychosexual development in adolescents and young adults with cancer. Pediatric Blood \& Cancer. 2007;49(6):824-8. doi:10.1002/pbc.21130.

32. Hudson MM, Tyc VL, Srivastava DK, Gattuso J, Quargnenti A, Crom DB et al. Multi-component behavioral intervention to promote health protective behaviors in childhood cancer survivors: The protect study. Medical and Pediatric Oncology. 2002;39(1):2-11. doi:10.1002/mpo.10071.

33. Santacroce SJ, Asmus K, Kadan-Lottick N, Grey M. Feasibility and preliminary outcomes from a pilot study of coping skills training for adolescent--young adult survivors of childhood cancer and their parents. Journal of Pediatric Oncology Nursing. 2010;27(1):10-20 11p. doi:10.1177/1043454209340325.

34. Mays D, Black JD, Mosher RB, Heinly A, Shad AT, Tercyak KP. Efficacy of the Survivor Health and Resilience Education (SHARE) Program to Improve Bone Health Behaviors Among Adolescent Survivors of Childhood Cancer. Annals of Behavioral Medicine. 2011;42(1):91-8. doi:10.1007/s12160011-9261-5. 
35. Hollen PJ, Tyc VL, Donnangelo SF, Shannon SV, O’Laughlen MC, Hinton I et al. A substance use decision aid for medically at-risk adolescents: results of a randomized controlled trial for cancersurviving adolescents. Cancer nursing. 2013;36(5):355-67.

36. Emmons KM, Puleo E, Park E, Gritz ER, Butterfield RM, Weeks JC et al. Peer-Delivered Smoking Counseling for Childhood Cancer Survivors Increases Rate of Cessation: The Partnership for Health Study. Journal of Clinical Oncology. 2005;23(27):6516-23.

37. Valle CG, Tate DF, Mayer DK, Allicock M, Cai J. A randomized trial of a Facebook-based physical activity intervention for young adult cancer survivors. Journal of Cancer Survivorship. 2013;7(3):355-68.

38. Bélanger LJ, Mummery WK, Clark AM, Courneya KS. Effects of targeted print materials on physical activity and quality of life in young adult cancer survivors during and after treatment: An exploratory randomized controlled trial. Journal of Adolescent and Young Adult Oncology. 2014;3(2):83-91. doi:10.1089/jayao.2013.0021.

39. Oeffinger KC, Hudson MM, Mertens AC, Smith SM, Mitby PA, Eshelman-Kent DA et al. Increasing rates of breast cancer and cardiac surveillance among high-risk survivors of childhood Hodgkin lymphoma following a mailed, one-page survivorship care plan. Pediatric blood \& cancer. 2011;56(5):818-24.

40. Høybye MT, Dalton SO, Deltour I, Bidstrup P, Frederiksen K, Johansen C. Effect of Internet peersupport groups on psychosocial adjustment to cancer: a randomised study. British journal of cancer. 2010;102(9):1348-54.

41. Rabin C, Dunsiger S, Ness KK, Marcus BH. Internet-based physical activity intervention targeting young adult cancer survivors. Journal of adolescent and young adult oncology. 2011;1(4):188-94.

42. Rabin C, Pinto B, Fava J. Randomized trial of a physical activity and meditation intervention for young adult cancer survivors. Journal of adolescent and young adult oncology. 2016;5(1):41-7.

43. National Cancer Institute. Adolescents and Young Adults with Cancer. 2016. https://www.cancer.gov/types/aya. Accessed 10/11/16.

44. Wiener L, Weaver MS, Bell CJ, Sansom-Daly UM. Threading the cloak: palliative care education for care providers of adolescents and young adults with cancer. Clinical oncology in adolescents and young adults. 2015;5:1.

45. Oeffinger KC, McCabe MS, Layne TM, Bach PB. Survivorship care plans in research and practice. Ca: a Cancer Journal for Clinicians. 2012;62(2):101.

46. Zebrack B, Kayser K, Padgett L, Sundstrom L, Jobin C, Nelson K et al. Institutional capacity to provide psychosocial oncology support services: a report from the Association of Oncology Social Work. Cancer. 2016;122(12):1937-45.

47. Moher D, Liberati A, Tetzlaff J, Altman DG, Group P. Preferred reporting items for systematic reviews and meta-analyses: the PRISMA statement. PLoS med. 2009;6(7):e1000097.

48. Blacklay A, Eiser C, Ellis A. Development and evaluation of an information booklet for adult survivors of cancer in childhood. The United Kingdom Children's Cancer Study Group Late Effects Group. Archives Of Disease In Childhood. 1998;78(4):340-4. 


\section{Box 1 Levels of Evidence [20]}

Level I Systematic review of RCTs, or evidence based guidelines based on systematic reviews of RCTs Level II Evidence from RCTs

Level III

Level IV

Level V

Level VI

Level VII

Evidence from controlled trials without randomisation

Evidence from case-control, cohort or before and after studies

Evidence from systematic reviews of descriptive and qualitative studies

Evidence from descriptive or qualitative studies

Evidence from opinion of authorities or expert committees 


\section{PRISMA Flow Diagram}
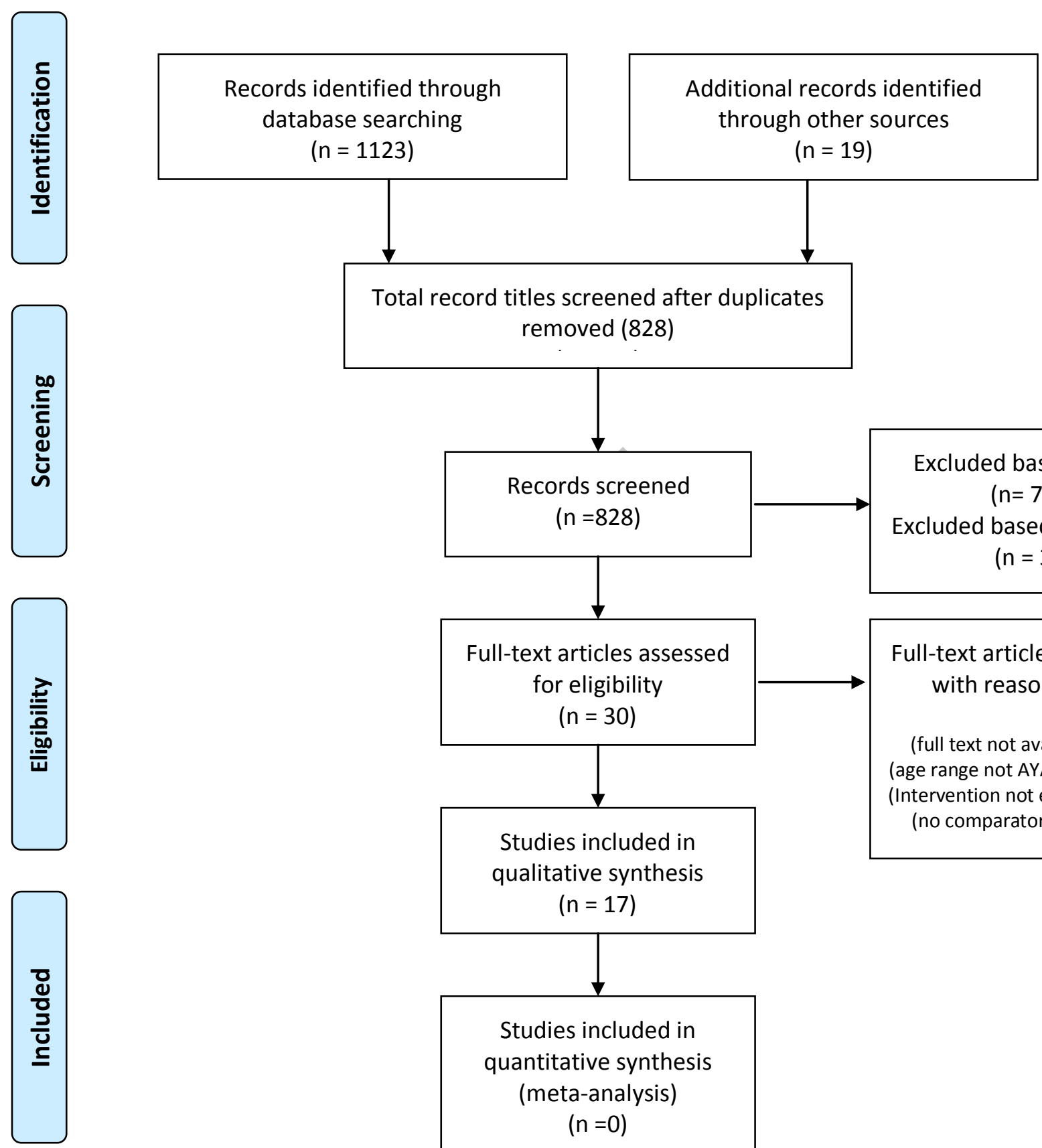

Excluded based on title $(n=768)$

Excluded based on abstract $(n=30)$

Full-text articles assessed for eligibility $(\mathrm{n}=30)$

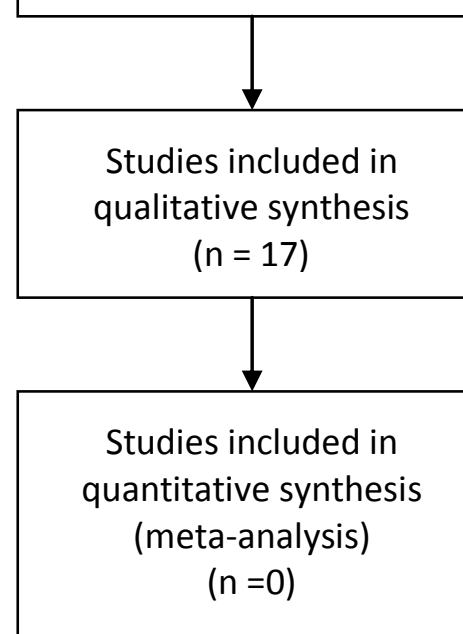

Full-text articles excluded, with reasons $n=13$

( full text not available $n=1$ ) (age range not AYA focused $n=7$ ) (Intervention not evaluated $n=3$ ) (no comparator group $n=2$ ) 
Table 1 Characteristics of included studies

\begin{tabular}{|c|c|c|c|c|c|c|c|c|}
\hline $\begin{array}{l}\text { Author, } \\
\text { Year, } \\
\text { Country }\end{array}$ & 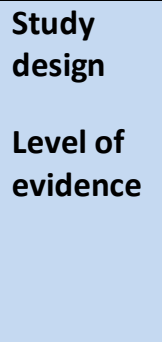 & Aims & $\begin{array}{l}\text { Characteristics of } \\
\text { participants: } \\
\text { sample size } \mathrm{N} \text {; } \\
\text { age at time of } \\
\text { study (mean time } \\
\text { since diagnosis in } \\
\text { years); response } \\
\text { rate; retention }\end{array}$ & $\begin{array}{l}\text { Content and } \\
\text { intensity of } \\
\text { intervention } \\
\text { (Follow up) }\end{array}$ & $\begin{array}{l}\text { Outcome } \\
\text { measures }\end{array}$ & Findings & $\begin{array}{l}\text { Effect size (\% change from } \\
\text { baseline) } \\
\text { mean difference, } 95 \% \mathrm{Cl} \\
\text { (P value) }\end{array}$ & Resources required and other notes \\
\hline \multicolumn{9}{|c|}{ Health Promotion Interventions } \\
\hline $\begin{array}{l}\text { Blaauwbroek } \\
\text { et al, 2009, } \\
\text { Netherlands } \\
{[30]}\end{array}$ & $\begin{array}{l}\text { Controlled } \\
\text { before and } \\
\text { after } \\
\text { III }\end{array}$ & $\begin{array}{l}\text { To evaluate the } \\
\text { effect of } \\
\text { enhanced daily } \\
\text { activity on fatigue } \\
\text { in adult survivors } \\
\text { of childhood } \\
\text { cancer }\end{array}$ & $\begin{array}{l}\text { Childhood cancer } \\
\text { survivors } \mathrm{N}=46 \\
\text { Mean age } 29.8 \text { years } \\
(21.8) \\
\text { Response rate } 56 \% \\
\text { Retention } 38 / 46(83 \%)\end{array}$ & $\begin{array}{l}\text { Intervention group ( } n= \\
\text { 46) received counselling } \\
\text { session re exercise } \\
\text { program, pedometer } \\
\text { and step diary. One } \\
\text { face-face session. } \\
\text { Control group ( } n=33 \text { ) } \\
\text { recruited by survivors } \\
\text { from healthy siblings or } \\
\text { peers. } \\
\text { (9 months FU) }\end{array}$ & $\begin{array}{l}\text { Fatigue, daily } \\
\text { physical } \\
\text { exercise }\end{array}$ & $\begin{array}{l}\text { Intervention was } \\
\text { effective in decreasing } \\
\text { fatigue in adult } \\
\text { survivors of childhood. } \\
\text { Fatigue and daily steps } \\
\text { walked improved. No } \\
\text { differences in control } \\
\text { group. High number of } \\
\text { withdrawals suggest } \\
\text { intervention may not } \\
\text { be suitable for all } \\
\text { patients }\end{array}$ & $\begin{array}{l}\text { Fatigue levels decreased } 21.8 \% \text { : } \\
\text { Mean Difference } 17.75(95 \% \mathrm{Cl} \\
1.12-1.48, \mathrm{p}=<0.005) \\
\text { Daily steps increased } 53.2 \% \\
\text { Mean Difference }-4.1(95 \% \mathrm{Cl} 0.57 \\
\text { to } 0.75, \mathrm{p}=<0.005)\end{array}$ & $\begin{array}{l}\text { No information provided for resources required. } \\
\text { Stated to be an economical intervention that } \\
\text { required no special facilities. } \\
\text { Intervention developed and delivered by } \\
\text { psychologist. Research assistant collected outcome } \\
\text { measures. } \\
\text { Small samples size and low response rate may } \\
\text { have biased selection of participants; results } \\
\text { suggestive rather than conclusive }\end{array}$ \\
\hline $\begin{array}{l}\text { Belanger et } \\
\text { al, 2014 } \\
\text { Canada, [38] }\end{array}$ & $\begin{array}{l}\text { Randomised } \\
\text { controlled } \\
\text { trial } \\
\|\end{array}$ & $\begin{array}{l}\text { To determine the } \\
\text { effects of a } \\
\text { printed physical } \\
\text { activity guidebook } \\
\text { targeted to young } \\
\text { adult cancer } \\
\text { survivors on } \\
\text { physical activity } \\
\text { and quality of life }\end{array}$ & $\begin{array}{l}\text { Young adult cancer } \\
\text { survivors } \mathrm{N}=212 \\
55 \text { patients aged } 18 \text { - } \\
29 \text { years ( } 26 \% \text { of total } \\
\mathrm{N}) \\
\text { Response rate } 11 \% \\
\text { Retention } 128 / 212 \\
(60 \%)\end{array}$ & $\begin{array}{l}\text { Intervention group } \\
\text { ( } n=106) \text { received printed } \\
\text { guidebook with planning } \\
\text { sheet; developed on } \\
\text { theory of planned } \\
\text { behaviour, assessed and } \\
\text { evaluated by experts } \\
\text { and consumers. Control } \\
\text { group ( } n=106) \text { received } \\
\text { Canadian Physical } \\
\text { Activity Guidelines. } \\
\text { (3 months FU) }\end{array}$ & $\begin{array}{l}\text { Physical } \\
\text { Activity, } \\
\text { Quality of life }\end{array}$ & $\begin{array}{l}\text { The guidebook did not } \\
\text { increase physical } \\
\text { activity compared to } \\
\text { generic guidelines in } \\
\text { highly active sample. } \\
\text { In subsample of } \\
\text { participants who } \\
\text { reported less than } 300 \\
\text { minutes/week of } \\
\text { exercise at baseline, } \\
\text { the intervention was } \\
\text { effective }\end{array}$ & $\begin{array}{l}\text { Increase in physical activity in } \\
\text { subsample ( } n=96 \text { ) of participants } \\
\text { reporting less than } 300 \\
\text { minutes/week of exercise } \\
\text { Physical activity increased by } \\
155 \% \text { in intervention group } \\
\text { compared to } 68 \% \text { in control } \\
\text { group. Mean difference }-82 \\
(95 \% \mathrm{Cl}-155.07 \text { to }-8.93 \text {, } \\
\mathrm{p}=0.028)\end{array}$ & $\begin{array}{l}\text { No stated information for resources required. } \\
\text { Intervention developed by team and based on } \\
\text { previous studies of young adult cancer survivors } \\
\text { preferences and determinant of physical exercise. } \\
\text { Participant self-selected and may be more } \\
\text { motivated to exercise. High attrition rate, wide } \\
\text { confidence intervals reduce the precision of effect } \\
\text { size; results suggestive rather than conclusive }\end{array}$ \\
\hline
\end{tabular}




\begin{tabular}{|c|c|c|c|c|c|c|c|c|}
\hline $\begin{array}{l}\text { Jarvela et al, } \\
\text { 2012, Finland } \\
{[26]}\end{array}$ & $\begin{array}{l}\text { Before and } \\
\text { after study } \\
\text { IV }\end{array}$ & $\begin{array}{l}\text { To evaluate the } \\
\text { effects of a } \\
\text { simple, home- } \\
\text { based exercise } \\
\text { program on } \\
\text { cardio-metabolic } \\
\text { risk factors, peak } \\
\text { oxygen uptake } \\
\text { and muscle } \\
\text { strength in AYA } \\
\text { long term } \\
\text { survivors of } \\
\text { childhood ALL }\end{array}$ & $\begin{array}{l}\text { Childhood cancer } \\
\text { survivors } \mathrm{N}=17 \\
\text { Mean age } 23 \text { years } \\
(16.7) \\
\text { Response rate } 22 \% \\
\text { Retention } 17 / 17 \\
(100 \%)\end{array}$ & $\begin{array}{l}\text { Home muscle training } \\
\text { program. Face-to-face } \\
\text { instruction and } \\
\text { Telephoned every } 2 \\
\text { weeks for motivation. } \\
\text { Matched controls } \\
\text { recruited from larger } \\
\text { study. } \\
\text { (4 months FU) }\end{array}$ & $\begin{array}{l}\text { Peak oxygen } \\
\text { uptake, } \\
\text { muscle } \\
\text { strength, } \\
\text { metabolic } \\
\text { factors }\end{array}$ & $\begin{array}{l}\text { Significant changes to } \\
\text { fasting insulin, waist } \\
\text { circumference, fat \% } \\
\text { and fitness in } \\
\text { participants. } \\
\text { Improved cardio- } \\
\text { metabolic risk factors. } \\
\text { Finding underline } \\
\text { positive changes can } \\
\text { be achieved with } \\
\text { modest improvements } \\
\text { in fitness. }\end{array}$ & $\begin{array}{l}\text { Volume oxygen }(\mathrm{ml} / \mathrm{kg} / \mathrm{min}) \\
\text { increased } 5.4 \% \text { Mean Difference } \\
-1.9(95 \% \mathrm{Cl}-3.33 \text { to }-0.44 \text {, } \\
\mathrm{p}=<0.01) \\
\text { Homeostasis model assessment, } \\
\text { insulin resistance decreased } 33 \% \\
\text { Mean Difference } 0.74(95 \% \mathrm{Cl} \\
0.12 \text { to } 1.66, \mathrm{p}=<0.01) \text {, } \\
\text { Fasting plasma insulin decreased } \\
30.4 \% \\
\text { Mean Difference } 3.06(95 \% \mathrm{Cl} \\
0.83 \text { to } 6.95, \mathrm{p}=<0.01)\end{array}$ & $\begin{array}{l}\text { No information provided for resources required. } \\
\text { Intervention delivered by exercise physiologist. No } \\
\text { information about existing exercise patterns. High } \\
\text { missing values for some outcome measures } \\
\text { Small sample size, low response rate and lack of } \\
\text { control group may have biased results; results } \\
\text { suggestive rather than conclusive }\end{array}$ \\
\hline $\begin{array}{l}\text { Keats et al, } \\
2008, \text { USA[24] }\end{array}$ & $\begin{array}{l}\text { Before and } \\
\text { after study } \\
\text { IV }\end{array}$ & $\begin{array}{l}\text { Examine } \\
\text { feasibility of } \\
\text { conducting theory } \\
\text { based physical } \\
\text { activity } \\
\text { intervention on } \\
\text { QoL }\end{array}$ & $\begin{array}{l}\text { Childhood cancer } \\
\text { survivors } \mathrm{N}=10 \\
\text { Mean age } 16.2 \text { years } \\
(5.2) \\
\text { Response rate not } \\
\text { determined } \\
\text { Retention } 10 / 11 \text { (91\%) }\end{array}$ & $\begin{array}{l}\text { Physical activity } \\
\text { intervention-meeting } \\
\text { once per week. } \\
\text { Delivered face-face in } \\
\text { group sessions over } 16 \\
\text { weeks } \\
\text { (12 month FU). }\end{array}$ & $\begin{array}{l}\text { Quality of life, } \\
\text { total physical } \\
\text { activity, } \\
\text { fatigue, } \\
\text { physical } \\
\text { fitness, } \\
\text { feasibility. }\end{array}$ & $\begin{array}{l}\text { Successful adherence } \\
\text { attributed to safe and } \\
\text { supervised } \\
\text { environment, } \\
\text { Improvements in } \\
\text { Quality of life and } \\
\text { fatigue at one year } \\
\text { post intervention } \\
\text { suggest physical } \\
\text { activity and fitness } \\
\text { positively influenced } \\
\text { by intervention }\end{array}$ & $\begin{array}{l}\text { Quality of life (Total score) } \\
\text { increase of } 14 \% \\
\text { Mean Difference }-9.9(95 \% \mathrm{Cl} \text { - } \\
23.46 \text { to } 3.67, p=0.05 \text { ) } \\
1 \text { mile walk/run (minutes) } \\
\text { decrease } 5.6 \% \\
\text { Mean Difference } 0.7 \text { ( } 95 \% \mathrm{Cl} 3.56 \\
\text { to } 4.96, p=0.01 \text { ) }\end{array}$ & $\begin{array}{l}\text { No information provided for resources required. } \\
\text { Intervention and assessment delivered by trained } \\
\text { instructor. Small heterogeneous sample, no } \\
\text { comparator group, possible self-selection bias; } \\
\text { results suggestive rather than conclusive }\end{array}$ \\
\hline $\begin{array}{l}\text { Valle et al, } \\
2013, \text { USA } \\
{[37]}\end{array}$ & $\begin{array}{l}\text { Randomised } \\
\text { controlled } \\
\text { trial } \\
\|\end{array}$ & $\begin{array}{l}\text { To determine } \\
\text { adherence to and } \\
\text { acceptability of } \\
\text { Facebook-based } \\
\text { intervention } \\
\text { approaches and } \\
\text { to evaluate } \\
\text { whether the } \\
\text { approaches would } \\
\text { produce } \\
\text { differences in } \\
\text { moderate-to- } \\
\text { vigorous intensity } \\
\text { physical activity }\end{array}$ & $\begin{array}{l}\text { Young adult cancer } \\
\text { survivors } \mathrm{N}=86 \\
\text { Mean age } 31 \\
\text { (4.9) } \\
\text { Response rate not } \\
\text { applicable; recruited } \\
\text { till sample size } \\
\text { achieved, } 89 \% \\
\text { consent rate } \\
\text { Retention } 66 / 86(77 \%)\end{array}$ & $\begin{array}{l}\text { Intervention group ( } n= \\
\text { 45) received physical } \\
\text { activity promotion } \\
\text { through Facebook group } \\
\text { delivered over Internet } \\
\text { over } 12 \text { weeks } \\
\text { (12 weeks FU) } \\
\text { Control group ( } n=41 \text { ) } \\
\text { had Facebook-based } \\
\text { self-help as comparator } \\
\text { Both groups used } \\
\text { pedometer }\end{array}$ & $\begin{array}{l}\text { Physical } \\
\text { activity, } \\
\text { feasibility, } \\
\text { body weight, } \\
\text { quality of life }\end{array}$ & $\begin{array}{l}\text { Both groups reported } \\
\text { increases in self- } \\
\text { reported physical } \\
\text { activity. Increases in } \\
\text { light physical activity } \\
\text { were greater in the } \\
\text { intervention group } \\
\text { who also achieved } \\
\text { weight loss. No } \\
\text { changes to quality of } \\
\text { life. }\end{array}$ & $\begin{array}{l}\text { Self-report physical activity } \\
\text { increase in both groups- } 112 \% \text { in } \\
\text { intervention group vs } 33 \% \text { in } \\
\text { control group } \\
\text { No significant changes between } \\
\text { groups: Mean Difference } 131.8 \\
(95 \% \mathrm{Cl} \text { ' }-119.34 \text { to } 382.94 \text {, } \\
\mathrm{p}=0.08) \\
\text { Intervention group decreased } \\
\text { body weight by } 7.8 \%, \text { Mean } \\
\text { Difference } 6.2(95 \% \mathrm{Cl}-2.91 \text { to } \\
15.31, \mathrm{p}=0.004)\end{array}$ & $\begin{array}{l}\text { Facebook-based intervention approach } \\
\text { demonstrated potential for increasing physical } \\
\text { activity in young adult cancer survivors. Social } \\
\text { networking sites may be a feasible way to promote } \\
\text { health behaviours and distribute health } \\
\text { information. Wide confidence intervals for } \\
\text { physical activity results reduces the precision of } \\
\text { the effect size; results suggestive rather than } \\
\text { conclusive }\end{array}$ \\
\hline Canada et al, & $\begin{array}{l}\text { Cross-over } \\
\text { randomised }\end{array}$ & $\begin{array}{l}\text { To test an } \\
\text { intervention }\end{array}$ & Childhood cancer & $\begin{array}{l}\text { Intervention group }(n= \\
\text { 10) received education }\end{array}$ & $\begin{array}{l}\text { Body image, } \\
\text { sexual }\end{array}$ & $\begin{array}{l}\text { Significant } \\
\text { improvement in }\end{array}$ & $\begin{array}{l}\text { Body image inventory improved } \\
\text { 13\%: Mean Difference - } 0.4 \text { (95\% }\end{array}$ & vided for resources required. \\
\hline
\end{tabular}




\begin{tabular}{|c|c|c|c|c|c|c|c|c|}
\hline 2007, USA[31] & $\begin{array}{l}\text { controlled } \\
\text { trial } \\
\text { II }\end{array}$ & $\begin{array}{l}\text { aimed to enhance } \\
\text { psychosexual } \\
\text { development in } \\
\text { adolescent and } \\
\text { young adults with } \\
\text { cancer }\end{array}$ & $\begin{array}{l}\text { survivors } \mathrm{N}=24 \text {, } \\
\text { Mean age 21yrs (1.9- } \\
\text { some still on active } \\
\text { treatment) } \\
\text { Response rate - no } \\
\text { information } \\
\text { Retention } 21 / 2488 \%\end{array}$ & $\begin{array}{l}\text { sessions. Behavioural } \\
\text { homework between } \\
\text { sessions. Booster phone } \\
\text { call at one month. Two } \\
\text { face-face sessions, }+ \\
\text { phone calls } \\
\text { ( } 3 \text { months FU) } \\
\text { Comparator group ( } n= \\
\text { 11) waitlisted to receive } \\
\text { intervention }\end{array}$ & $\begin{array}{l}\text { concerns, } \\
\text { cancer } \\
\text { rehabilitation } \\
\text { and brief } \\
\text { symptom } \\
\text { inventory of } \\
\text { overall } \\
\text { distress. }\end{array}$ & $\begin{array}{l}\text { cancer related sexual } \\
\text { knowledge, } \\
\text { confidence about } \\
\text { appearance, body } \\
\text { perception, less } \\
\text { dissatisfaction with } \\
\text { body parts, decrease } \\
\text { in sexual concerns, } \\
\text { and decrease in } \\
\text { emotional distress. }\end{array}$ & $\begin{array}{l}\mathrm{Cl}-0.82 \text { to } 0.02, \mathrm{p}=<0.001) \\
\text { Cancer related sexual knowledge } \\
\text { improved } 27 \% \text { : Mean Difference } \\
-3.63(95 \% \mathrm{Cl}-5.37 \text { to }-1.89 \text {, } \\
\mathrm{p}=<0.001) \\
\text { Body competence scores } \\
\text { improved } 11 \% \text { : Mean Difference } \\
-0.3(95 \% \mathrm{Cl}-0.78 \text { to } 0.18 \text {, } \\
\mathrm{p}=<0.05) \\
\text { Psychological distress decreased } \\
\text { by } 49 \% \text { : Mean difference } 11.53 \\
(95 \% \mathrm{Cl} 3.18 \text { to } 19.88, \mathrm{p}=<0.005)\end{array}$ & $\begin{array}{l}\text { Intervention developed and delivered by doctoral } \\
\text { level psychologist. Authors acknowledge } \\
\text { difficulties with recruitment, several hundred } \\
\text { contacted, only } 35 \text { verbally agreed and only } 24 \\
\text { participated. Treatment completed for } 63 \% \text { of } \\
\text { participants. Sample most likely biased- } \\
\text { counselling more attractive to those with } \\
\text { problems. } \\
\text { Intervention likely of interest only to those with } \\
\text { significant problems. } \\
\text { Sample most likely biased, self-selected; results } \\
\text { suggestive rather than conclusive }\end{array}$ \\
\hline $\begin{array}{l}\text { Eiser et al, } \\
\text { 2000, UK [29] }\end{array}$ & $\begin{array}{l}\text { Before and } \\
\text { after study } \\
\text { IV }\end{array}$ & $\begin{array}{l}\text { To replicate } \\
\text { previous findings } \\
\text { from Blacklay } \\
\text { 1998[48]. To } \\
\text { assess effects } \\
\text { following the } \\
\text { intervention of } \\
\text { survivors } \\
\text { readiness for } \\
\text { change; self- } \\
\text { efficacy or } \\
\text { competence; to } \\
\text { determine the } \\
\text { negative } \\
\text { consequences of } \\
\text { the intervention }\end{array}$ & $\begin{array}{l}\text { Childhood cancer } \\
\text { survivors } \mathrm{N}=263 \text {, } \\
\text { Mean age 21yrs (14.4) } \\
\text { Response rate } 87 \% \\
\text { Retention } 155 / 263 \\
(59 \%)\end{array}$ & $\begin{array}{l}\text { Information package } \\
\text { including treatment } \\
\text { summary and specific } \\
\text { information sheets } \\
\text { related to problems. } \\
\text { Face-face instructions at } \\
\text { clinic } \\
\text { ( } 2 \text { weeks FU) }\end{array}$ & $\begin{array}{l}\text { Perceived } \\
\text { importance } \\
\text { of follow-up; } \\
\text { readiness to } \\
\text { change; self- } \\
\text { efficacy; } \\
\text { perceived } \\
\text { vulnerability }\end{array}$ & $\begin{array}{l}\text { Unable to replicate } \\
\text { previous findings. } \\
\text { Authors acknowledge } \\
\text { those with least } \\
\text { positive attitude were } \\
\text { likely less likely to } \\
\text { reply to follow-up } \\
\text { questionnaires. } \\
\text { Unable to target } \\
\text { survivors who were } \\
\text { not attending a clinic }\end{array}$ & $\begin{array}{l}\text { No change in ratings of } \\
\text { importance of follow-up between } \\
\text { two assessment times. }\end{array}$ & $\begin{array}{l}\text { No information provided for resources required. } \\
\text { Intervention developed by large team. Delivered } \\
\text { by medical staff and nurses, required printed } \\
\text { booklets. Large lost to follow-up; } 41 \% \text { did not } \\
\text { agree to be in study or did not return } \\
\text { questionnaire. } \\
\text { Results suggestive of benefit for intervention. } \\
\text { Authors recommend information should be given } \\
\text { throughout treatment rather than at completion } \\
\text { alone }\end{array}$ \\
\hline
\end{tabular}




\begin{tabular}{|c|c|c|c|c|c|c|c|c|}
\hline $\begin{array}{l}\text { Hudson et al, } \\
2002 \text {, USA } \\
{[32]}\end{array}$ & $\begin{array}{l}\text { Randomised } \\
\text { controlled } \\
\text { trial } \\
\|\end{array}$ & $\begin{array}{l}\text { To assess the } \\
\text { impact of a multi- } \\
\text { component } \\
\text { behavioural } \\
\text { health promotion } \\
\text { study }\end{array}$ & $\begin{array}{l}\text { Childhood cancer } \\
\text { survivors } N=266 \\
\text { Mean age } 15.1 \text { years } \\
(10.63) \\
\text { Response rate } 86 \% \\
\text { Retention } 252 / 266 \\
(95 \%)\end{array}$ & $\begin{array}{l}\text { Intervention group } \\
(\mathrm{n}=131) \text { received } \\
\text { educational counselling } \\
\text { intervention to increase } \\
\text { practice of health- } \\
\text { protective behaviours. } \\
\text { One individual training } \\
\text { module face-to-face, } \\
\text { written materials, } 2 \\
\text { telephone calls } \\
\text { (12 months FU) } \\
\text { Control group ( } n=135) \\
\text { received standard care }\end{array}$ & $\begin{array}{l}\text { Health } \\
\text { protective } \\
\text { questionnaire } \\
\text {, health } \\
\text { knowledge, } \\
\text { perceived: } \\
\text { susceptibility; } \\
\text { seriousness; } \\
\text { benefits; } \\
\text { barriers, } \\
\text { health } \\
\text { practices }\end{array}$ & $\begin{array}{l}\text { No significant } \\
\text { difference at one year } \\
\text { between groups. } \\
\text { More intensive } \\
\text { intervention is most } \\
\text { likely needed. }\end{array}$ & $\begin{array}{l}\text { No significant differences } \\
\text { between groups } \\
\text { Females were more likely to } \\
\text { increase knowledge at } 12 \text { months } \\
\text { compared to males }(p=0.02)\end{array}$ & $\begin{array}{l}\text { No information provided regarding resources } \\
\text { required. } \\
\text { Clinical assessments by physician, nurse } \\
\text { practitioner or psychologist. } \\
\text { Results suggestive rather than conclusive. }\end{array}$ \\
\hline $\begin{array}{l}\text { Kunin-Baston } \\
\text { et al, 2015, } \\
\text { USA [23] }\end{array}$ & $\begin{array}{l}\text { Randomised } \\
\text { controlled } \\
\text { trial } \\
\|\end{array}$ & $\begin{array}{l}\text { To measure } \\
\text { cancer knowledge } \\
\text { and } \\
\text { understanding of } \\
\text { late effects } \\
\text { among AYA } \\
\text { survivors and to } \\
\text { develop and test a } \\
\text { web based } \\
\text { resource }\end{array}$ & $\begin{array}{l}\text { Childhood cancer } \\
\text { survivors } \mathrm{N}=52, \\
\text { Mean age 21yrs (12.2) } \\
\text { Response rate } 59 \% \\
\text { Retention } 38 / 52 \text { (73\%) }\end{array}$ & $\begin{array}{l}\text { Intervention group } \\
(\mathrm{n}=26) \text { received access } \\
\text { to a web portal with } \\
\text { personalised } \\
\text { information, journal, } \\
\text { links to information and } \\
\text { messaging to healthcare } \\
\text { professionals. Face-to- } \\
\text { face instructions and } \\
\text { email instructions (12 } \\
\text { months FU) } \\
\text { Control group ( } \mathrm{n}=26) \\
\text { received standard care }\end{array}$ & $\begin{array}{l}\text { Cancer } \\
\text { knowledge, } \\
\text { state trait } \\
\text { anxiety, } \\
\text { computer } \\
\text { knowledge, } \\
\text { website use } \\
\text { and } \\
\text { satisfaction }\end{array}$ & $\begin{array}{l}\text { No difference } \\
\text { between groups, } \\
\text { intervention had no } \\
\text { effect. Offering } \\
\text { educational } \\
\text { information in person } \\
\text { or by Web does not } \\
\text { appear to be enough } \\
\text { to close the gap. }\end{array}$ & $\begin{array}{l}\text { No significant differences } \\
\text { between groups }\end{array}$ & $\begin{array}{l}\text { No information provided regarding resources } \\
\text { required. Developed a web portal and } \\
\text { personalised summary sheets for study- less than } \\
50 \% \text { of participants used this resource } \\
\text { High lost to follow-up (27\%) } \\
\text { Results do not support intervention, but identified } \\
\text { need to education in this patient group; less than } \\
\text { half of participants recognised the risk previous } \\
\text { treatment for cancer posed. }\end{array}$ \\
\hline $\begin{array}{l}\text { Mays et al, } \\
\text { 2011, USA } \\
{[34]}\end{array}$ & $\begin{array}{l}\text { Randomised } \\
\text { controlled } \\
\text { trial } \\
\text { II }\end{array}$ & $\begin{array}{l}\text { To examine the } \\
\text { efficacy of } \\
\text { survivor health } \\
\text { and resilience } \\
\text { education to } \\
\text { immediately } \\
\text { improve bone } \\
\text { health }\end{array}$ & $\begin{array}{l}\text { Childhood cancer } \\
\text { survivors } N=75 \text {, } \\
\text { Mean age } 14.2 \text { years } \\
\text { (3.4) } \\
\text { Response rate } 49 \% \\
\text { Retention not } \\
\text { reported }\end{array}$ & $\begin{array}{l}\text { Intervention group ( } \mathrm{n}= \\
38 \text { ) received skill } \\
\text { building exercises } \\
\text { addressing risk taking } \\
\text { behaviour. Bone health } \\
\text { education, and } \\
\text { discussion of } \\
\text { recommended dietary } \\
\text { calcium intake, role } \\
\text { laying, food tasting. One } \\
\text { face-face session } \\
\text { (1 month FU) }\end{array}$ & $\begin{array}{l}\text { Bone health } \\
\text { measured by } \\
\text { calcium } \\
\text { consumption } \\
\text { and bone } \\
\text { health } \\
\text { behaviours }\end{array}$ & $\begin{array}{l}\text { Study suggests } \\
\text { intervention was well } \\
\text { received, relevant, } \\
\text { understandable, } \\
\text { beneficial and } \\
\text { acceptable. } \\
\text { Potentially important } \\
\text { for long term health of } \\
\text { survivors }\end{array}$ & $\begin{array}{l}\text { Milk consumption increase in } \\
\text { intervention group at one month: } \\
\text { Mean difference } 0.43(95 \% \mathrm{Cl} \\
0.05 \text { to } 0.81, p=0.03) \text {. } \\
\text { Intervention group were } 24.5 \\
\text { times as likely to take calcium } \\
\text { supplement ( } p=<0.001)\end{array}$ & $\begin{array}{l}\text { No information provided regarding resources } \\
\text { required. } \\
\text { Intervention delivered by dietician who was } \\
\text { member of research team. Limited follow up, } \\
\text { small sample size, self-report measures developed } \\
\text { for this study; results suggestive rather than } \\
\text { conclusive. }\end{array}$ \\
\hline
\end{tabular}




\begin{tabular}{|c|c|c|c|c|c|c|c|c|}
\hline & & & & $\begin{array}{l}\text { Control group ( } n=37) \\
\text { waitlisted and offered } \\
\text { intervention at } \\
\text { conclusion of study }\end{array}$ & & & & \\
\hline $\begin{array}{l}\text { Tyc et al, } \\
\text { 2003, USA } \\
\text { [22] }\end{array}$ & $\begin{array}{l}\text { Randomised } \\
\text { controlled } \\
\text { trial } \\
\|\end{array}$ & $\begin{array}{l}\text { To evaluate the } \\
\text { efficacy of } \\
\text { tobacco risk } \\
\text { counselling } \\
\text { intervention } \\
\text { compared to } \\
\text { standard care }\end{array}$ & $\begin{array}{l}\text { Childhood cancer } \\
\text { survivors } N=103 \text {, } \\
\text { Mean age 15yrs (6.3) } \\
\text { Response rate } 86.5 \% \\
\text { Retention } 81 / 103 \\
(79 \%)\end{array}$ & $\begin{array}{l}\text { Intervention group } \\
(\mathrm{n}=53) \text { received } \\
\text { educational counselling, } \\
\text { on late-effects and } \\
\text { toxicities exacerbated by } \\
\text { tobacco. Single } \\
\text { educational session with } \\
\text { periodic re-enforcement } \\
\text { by telephone. } \\
\text { (12 months FU) } \\
\text { Control arm }(n=50) \\
\text { received standard care }\end{array}$ & $\begin{array}{l}\text { Self-reported } \\
\text { knowledge, } \\
\text { perceived } \\
\text { vulnerability, } \\
\text { intention to } \\
\text { use tobacco } \\
\text { and } \\
\text { perceived } \\
\text { positive } \\
\text { effects of } \\
\text { tobacco use }\end{array}$ & $\begin{array}{l}\text { Results indicate } \\
\text { tobacco related } \\
\text { knowledge, perceived } \\
\text { vulnerability and } \\
\text { intention to use } \\
\text { tobacco can be } \\
\text { modified with risk } \\
\text { counselling } \\
\text { intervention. } \\
\text { Feasibility of the } \\
\text { program also } \\
\text { established. } \\
\text { Intervention did not } \\
\text { have an effect on } \\
\text { patients who used } \\
\text { tobacco. }\end{array}$ & No significant group differences & $\begin{array}{l}\text { No information provided regarding resources } \\
\text { required. } \\
\text { Intervention delivered by masters level } \\
\text { psychologist. Outcomes collected by research } \\
\text { nurse. Only } 70 \% \text { of patients provided data at } 6 \text { and } \\
12 \text { months. No differences in the smoking status } \\
\text { across time; delayed effect of intervention at } 12 \\
\text { months indicated modification takes time. } \\
\text { Results suggestive rather than conclusive. }\end{array}$ \\
\hline \multicolumn{9}{|c|}{ Psychological Interventions } \\
\hline $\begin{array}{l}\text { Emmons et al, } \\
2005 \text {, USA } \\
{[36]}\end{array}$ & $\begin{array}{l}\text { Randomised } \\
\text { controlled } \\
\text { trial } \\
\|\end{array}$ & $\begin{array}{l}\text { To evaluate the } \\
\text { impact of a peer- } \\
\text { based telephone } \\
\text { counselling } \\
\text { intervention on } \\
\text { smoking among } \\
\text { childhood cancer } \\
\text { survivors }\end{array}$ & $\begin{array}{l}\text { Childhood cancer } \\
\text { survivors } \mathrm{N}=796 \\
\text { Mean age } 31 \text { (50\% } \\
\text { diagnosed before age } \\
9 \text { years) } \\
\text { Response rate } 83 \% \\
\text { Retention } 616 / 796 \\
(77 \%)\end{array}$ & $\begin{array}{l}\text { Intervention group ( } \mathrm{n}= \\
\text { 398) assigned a } \\
\text { counsellor who was also } \\
\text { a childhood cancer } \\
\text { survivor provided } \\
\text { motivational } \\
\text { interviewing to cease } \\
\text { smoking. Written } \\
\text { report, supplementary } \\
\text { material sent. Telephone } \\
\text { counselling average 6 } \\
\text { calls } \\
\text { (12 months FU) } \\
\text { Control group (398) } \\
\text { received self-help } \\
\text { information }\end{array}$ & $\begin{array}{l}\text { Quit rate- } \\
\text { smoking } \\
\text { status, } \\
\text { number of } \\
\text { quit } \\
\text { attempts, } \\
\text { nicotine } \\
\text { replacement } \\
\text { treatment, } \\
\text { self-efficacy, } \\
\text { perceived } \\
\text { vulnerability, } \\
\text { perceived } \\
\text { medical } \\
\text { outcomes }\end{array}$ & $\begin{array}{l}\text { Intervention did not } \\
\text { have an effect on } \\
\text { efforts to quit, but } \\
\text { rather the likelihood } \\
\text { that those efforts } \\
\text { would be successful. } \\
\text { Predictors of cessation } \\
\text { identified: short term } \\
\text { and long term self- } \\
\text { efficacy were related } \\
\text { to smoking cessation. } \\
\text { Individuals with high } \\
\text { self-efficacy were } 4 \\
\text { times more likely to } \\
\text { quit than those with } \\
\text { little or no self- } \\
\text { efficacy. }\end{array}$ & $\begin{array}{l}\text { Quit rate for smoking was higher } \\
\text { in the intervention group } \\
\text { compared to self-help group: } \\
15 \% \text { vs } 9 \% \text {, Odds Ratio } 1.7 \text { ( } 95 \% \mathrm{Cl} \\
1.05 \text { to } 2.63, p=<0.05) \text {. } \\
\text { Controlling for baseline self - } \\
\text { efficacy and depression, } \\
\text { intervention group was likely to } \\
\text { quit smoking compared with } \\
\text { control group, Odds Ratio } 1.99 \\
(95 \% \mathrm{Cl} 1.27 \text { to } 3.14, p=<0.05) \\
14.5 \% \text { of all participants quit } \\
\text { smoking at follow up. }\end{array}$ & $\begin{array}{l}\text { Per person cost for intervention estimated at } \\
\text { USD\$300 per person. Nicotine patches provided } \\
\text { free by Pharma. Information provided for peer and } \\
\text { staff salary and variable costs } \\
\text { Intervention delivered by peers, supervised by } \\
\text { staff. Free nicotine patches may have influenced } \\
\text { the outcomes- in the control group participants } \\
\text { had to buy their own patches where as they were } \\
\text { provided freely in the intervention group. } 33 \% \text { of } \\
\text { intervention group used nicotine patches } \\
\text { compared with just } 8 \% \text { in control group. } \\
\text { Significantly higher quit rates in those who used } \\
\text { nicotine patches. } \\
\text { Results suggestive rather than conclusive }\end{array}$ \\
\hline
\end{tabular}




\begin{tabular}{|c|c|c|c|c|c|c|c|c|}
\hline $\begin{array}{l}\text { Fisher et al, } \\
\text { 2015, UK [25] }\end{array}$ & $\begin{array}{l}\text { Before and } \\
\text { after study } \\
\text { IV }\end{array}$ & $\begin{array}{l}\text { To establish } \\
\text { feasibility and } \\
\text { potential efficacy } \\
\text { of metacognitive } \\
\text { therapy for AYA } \\
\text { cancer survivors } \\
\text { experiencing } \\
\text { clinically } \\
\text { significant distress }\end{array}$ & $\begin{array}{l}\text { Childhood cancer } \\
\text { survivors } \mathrm{N}=12 \\
\text { Mean age 20yrs (7.7) } \\
\text { Response rate } 40 \% \\
\text { Retention } 10 / 12(83 \%)\end{array}$ & $\begin{array}{l}\text { Individual treatment } \\
\text { with metacognitive } \\
\text { therapy ( } 45-60 \text { minutes } \\
\text { long) over } 12 \text { face-face } \\
\text { sessions } \\
\text { ( } 6 \text { month FU). }\end{array}$ & $\begin{array}{l}\text { Anxiety } \\
\text { (HADS) and } \\
\text { Impact of } \\
\text { event (scale } \\
\text { measuring } \\
\text { trauma } \\
\text { related } \\
\text { symptoms) }\end{array}$ & $\begin{array}{l}\text { Statistically significant } \\
\text { improvements across } \\
\text { all symptoms } \\
\text { indicating intervention } \\
\text { was effective. Most } \\
\text { participants showed at } \\
\text { least reliable } \\
\text { improvement with } \\
50 \% \text { classified as } \\
\text { recovered. }\end{array}$ & $\begin{array}{l}\text { Anxiety total score decreased by } \\
59 \% \text { at follow up: Mean } \\
\text { Difference } 11.83(95 \% \mathrm{Cl} 6.10 \text { to } \\
17.56, p=<0.001) \\
\text { Impact of event total score } \\
\text { decreased by } 76 \% \text { at follow up: } \\
\text { Mean difference } 33.09(95 \% \mathrm{Cl} \\
19.30 \text { to } 46.88, p=<0.001)\end{array}$ & $\begin{array}{l}\text { No information provided for resources required. } \\
\text { Provides preliminary evidence of the effectiveness } \\
\text { of MCT in alleviating anxiety, depression and post- } \\
\text { traumatic symptoms. Longer follow up would have } \\
\text { been desirable } \\
\text { Intervention developed and delivered and } \\
\text { measured by psychologist (no independent } \\
\text { assessment of treatment outcome). Small samples } \\
\text { size, } 34 \% \text { response rate and } 17 \% \text { lost to follow up, } \\
\text { no comparator group; results suggestive rather } \\
\text { than conclusive but demonstrate feasibility }\end{array}$ \\
\hline $\begin{array}{l}\text { Hollen et al, } \\
\text { 1999, USA } \\
{[28]}\end{array}$ & $\begin{array}{l}\text { Controlled } \\
\text { before and } \\
\text { after study }\end{array}$ & $\begin{array}{l}\text { To test the effects } \\
\text { of a decision- } \\
\text { making and risk } \\
\text { reduction } \\
\text { program for } \\
\text { cancer-surviving } \\
\text { adolescents }\end{array}$ & $\begin{array}{l}\text { Childhood cancer } \\
\text { survivors } \mathrm{N}=64 \\
\text { Age range } 13-21 \\
\text { years. (50\% diagnosed } \\
\text { before age of } 6 \text { years) } \\
\text { Response rate for } \\
\text { intervention } 61.5 \% \\
\text { Retention } 56 / 6488 \%\end{array}$ & $\begin{array}{l}\text { Intervention group } \\
(\mathrm{n}=21) \text { attended } \\
\text { workshop on decision } \\
\text { making skills, risk } \\
\text { behaviour and social } \\
\text { support + audio/video } \\
\text { recordings. One face- } \\
\text { face session and } \\
\text { individual components } \\
\text { (12 months FU) } \\
\text { Control group ( } \mathrm{n}=43) \\
\text { were intervention } \\
\text { refusers }\end{array}$ & $\begin{array}{l}\text { Decision } \\
\text { making, risk } \\
\text { motivation, } \\
\text { risk } \\
\text { behaviours }\end{array}$ & $\begin{array}{l}\text { Intervention produced } \\
\text { short term effects at } 1 \\
\text { and } 6 \text { months for } \\
\text { smoking, and a long- } \\
\text { term dampening, but } \\
\text { marginal effect for } \\
\text { alcohol. Results may } \\
\text { be subject to bias. }\end{array}$ & $\begin{array}{l}\text { Regression model controlling for } \\
\text { age, gender and site: Decision } \\
\text { making scores improved by } 11 \% \\
\text { in intervention group and } \\
\text { decreased by } 1.3 \% \text { in control } \\
\text { group: The intervention } \\
\text { accounted for } 27 \% \text { of variance in } \\
\text { decision making at } 12 \text { months. } \\
\text { Mean difference in intervention } \\
\text { group }-0.34 \text { ( } p=0.001) \text {; Mean } \\
\text { difference in control group } 1.79 \\
(p=0.01)\end{array}$ & $\begin{array}{l}\text { No information provided for resources required. } \\
\text { Intervention delivered by a counsellor, one home } \\
\text { visit and telephone support. Intervention group } \\
\text { baselines scores significantly lower than control } \\
\text { group, follow up scores between two groups very } \\
\text { similar } \\
\text { Authors acknowledge intervention arm self- } \\
\text { selected and may have been more motivated; } \\
\text { results suggestive rather than conclusive }\end{array}$ \\
\hline $\begin{array}{l}\text { Hollen et al, } \\
2013, \text { USA } \\
{[35]}\end{array}$ & $\begin{array}{l}\text { Randomised } \\
\text { controlled } \\
\text { trial } \\
\|\end{array}$ & $\begin{array}{l}\text { To definitively } \\
\text { confirm the } \\
\text { results of an } \\
\text { earlier pilot study } \\
\text { (Hollen } 1999 \\
\text { above) with more } \\
\text { diverse sample in } \\
\text { more diverse } \\
\text { setting } \\
\text { To test the effects }\end{array}$ & $\begin{array}{l}\text { Childhood cancer } \\
\text { survivors } \mathrm{N}=243 \text {, } \\
\text { Mean age } 16.3 \text { years } \\
\text { (11.2) } \\
\text { Response rate - no } \\
\text { information } \\
\text { Retention } 75 \%\end{array}$ & $\begin{array}{l}\text { Intervention arm } \\
(n=102) \text { had tailored risk } \\
\text { taking behaviour } \\
\text { counselling One face-to- } \\
\text { face session, } 5 \text { online } \\
\text { modules. Email and } \\
\text { phone contact } \\
(12 \text { months FU) } \\
\text { Control arm ( } n=111) \\
\text { received usual care }\end{array}$ & $\begin{array}{l}\text { Decision } \\
\text { making, risk } \\
\text { motivation, } \\
\text { substance use } \\
\text { behaviours }\end{array}$ & $\begin{array}{l}\text { Some immediate } \\
\text { change in substance } \\
\text { use motivation. } \\
\text { Feasibility established, } \\
\text { but adherence difficult } \\
\text { to maintain. Overall } \\
\text { effects of intervention } \\
\text { were modest, but } \\
\text { program was rated } \\
\text { highly. }\end{array}$ & $\begin{array}{l}\text { No significant effect in either } \\
\text { group for decision making, risk } \\
\text { motivation or reduced substance } \\
\text { use behaviours. }\end{array}$ & $\begin{array}{l}\text { No information provided regarding resources } \\
\text { required. Developed a CD rom for study } \\
\text { Intervention delivered by nurse practitioners } \\
\text { Baseline data suggested substance use risk was } \\
\text { high indicating cancer survivors taking } \\
\text { unacceptable risks with health. Significant number } \\
\text { of participants didn't complete all modules, } 30 \\
\text { withdrew or lost to follow up }\end{array}$ \\
\hline
\end{tabular}




\begin{tabular}{|c|c|c|c|c|c|c|c|c|}
\hline & & $\begin{array}{l}\text { of a decision- } \\
\text { making and risk } \\
\text { reduction } \\
\text { program for } \\
\text { cancer-surviving } \\
\text { adolescents }\end{array}$ & & & & & & Results suggestive rather than conclusive. \\
\hline $\begin{array}{l}\text { Santacroce et } \\
\text { al, 2010, USA } \\
{[33]}\end{array}$ & $\begin{array}{l}\text { Randomised } \\
\text { controlled } \\
\text { trial } \\
\|\end{array}$ & $\begin{array}{l}\text { To assess the } \\
\text { feasibility of } \\
\text { coping skills } \\
\text { training in terms } \\
\text { of recruitment, } \\
\text { retention. }\end{array}$ & $\begin{array}{l}\text { Childhood cancer } \\
\text { survivors } \mathrm{N}=21 \text { (and } \\
20 \text { parents also } \\
\text { recruited) } \\
\text { Mean age } 21 \text { years } \\
(11.2) \\
\text { Response rate } 88 \% \\
\text { Retention } 19 / 21(90 \%)\end{array}$ & $\begin{array}{l}\text { Intervention arm ( } n=9) \\
\text { received coping skills } \\
\text { training aimed to help } \\
\text { non-ill youth develop } \\
\text { strategies for managing } \\
\text { stress. Seven telephone } \\
\text { sessions } \\
\text { ( } 3 \text { months FU) } \\
\text { Control arm received } \\
\text { usual care ( } n=11)\end{array}$ & $\begin{array}{l}\text { Uncertainty, } \\
\text { anxiety, Post } \\
\text { traumatic } \\
\text { Stress, } \\
\text { benefits } \\
\text { finding and } \\
\text { health } \\
\text { promotion } \\
\text { behaviours }\end{array}$ & $\begin{array}{l}\text { Outcomes for } \\
\text { comparator group } \\
\text { remained the same or } \\
\text { deteriorated while } \\
\text { outcomes intervention } \\
\text { group improved. } \\
\text { Small sample size } \\
\text { reduces precision of } \\
\text { results. Significant } \\
\text { delay in obtaining } \\
\text { outcome measures at } \\
\text { both baseline and end } \\
\text { of intervention }\end{array}$ & $\begin{array}{l}\text { Small sample size prohibited use } \\
\text { of inferential statistics. Results } \\
\text { presented as trends graphically }\end{array}$ & $\begin{array}{l}\text { No information provided regarding resources } \\
\text { required. } \\
\text { Intervention delivered by interventionist who } \\
\text { received training and supervision } \\
\text { Results suggestive of intervention benefit and } \\
\text { support feasibility. }\end{array}$ \\
\hline $\begin{array}{l}\text { Seitz et al, } \\
\text { 2014, } \\
\text { Germany [27] }\end{array}$ & $\begin{array}{l}\text { Before and } \\
\text { after study } \\
\text { IV }\end{array}$ & $\begin{array}{l}\text { To develop and } \\
\text { test a therapist } \\
\text { guided cognitive } \\
\text { behavioural } \\
\text { intervention using } \\
\text { web based } \\
\text { therapy }\end{array}$ & $\begin{array}{l}\begin{array}{l}\text { Childhood cancer } \\
\text { survivors } \mathrm{N}=20 \text {, } \\
\text { Mean age } 27 \text { years } \\
(13.8)\end{array} \\
\text { Response rate } 71 \% \\
\text { Retention } 14 / 2070 \%\end{array}$ & $\begin{array}{l}\text { Internet based } \\
\text { psychological } \\
\text { intervention- to } \\
\text { reprocess traumatic } \\
\text { cancer experiences and } \\
\text { build coping strategies. } \\
10 \text { internet sessions over } \\
5 \text { weeks. Treatment } \\
\text { delivered by written } \\
\text { messages on Internet } \\
\text { platform. } \\
\text { (3 months FU) }\end{array}$ & $\begin{array}{l}\text { Post- } \\
\text { traumatic } \\
\text { stress } \\
\text { diagnostic } \\
\text { scale, } \\
\text { Hospital } \\
\text { Anxiety and } \\
\text { depression } \\
\text { scale (HADS) } \\
\text { and fear or } \\
\text { progression/r } \\
\text { elapse } \\
\text { questionnaire }\end{array}$ & $\begin{array}{l}\text { Significant reduction } \\
\text { in PTSD and anxiety } \\
\text { and clinically relevant } \\
\text { improzement- } \\
\text { treatment effects } \\
\text { were sustained for } \\
\text { those participants that } \\
\text { could be followed up. }\end{array}$ & 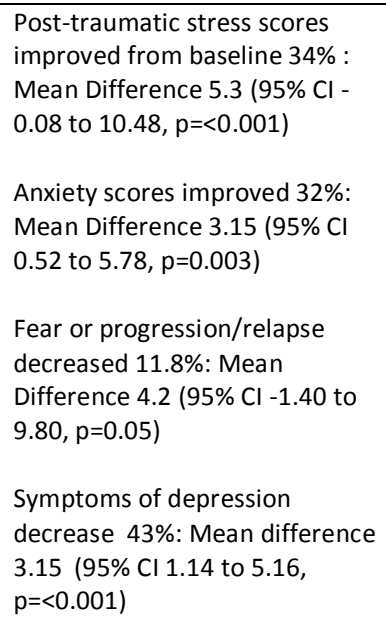 & $\begin{array}{l}\text { No information provided for resources required. } \\
\text { Intervention delivered psychologists. Younger } \\
\text { patients may prefer games or websites. Promising } \\
\text { result- bigger studies needs with multivariate } \\
\text { analysis- author's state results justify an RCT. } \\
\text { No comparator group, small sample size, large } \\
\text { number of lost to follow up/withdrawals; results } \\
\text { suggestive rather than conclusive }\end{array}$ \\
\hline
\end{tabular}


HADS Hospital Anxiety and Depression Scale

PTSD Post Traumatic Stress Disorder 
Table 2. Intervention focus, outcome measures, attributes and Risk of Bias of included studies

\begin{tabular}{|c|c|c|c|c|c|c|c|c|c|c|c|c|c|c|c|c|c|}
\hline \multirow[t]{2}{*}{ Attributes of interventions } & \multicolumn{11}{|c|}{ Health Promotion Interventions } & \multicolumn{6}{|c|}{ Psychological interventions } \\
\hline & 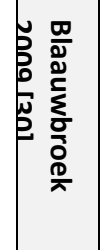 & 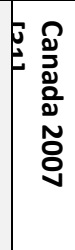 & 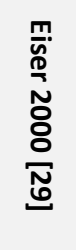 & 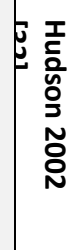 & 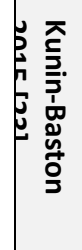 & 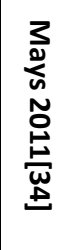 & 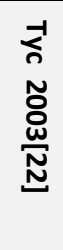 & 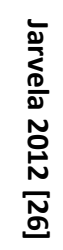 & 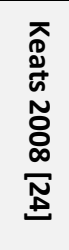 & 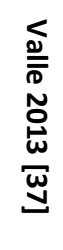 & 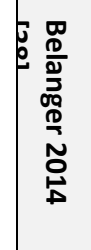 & 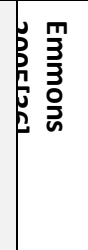 & 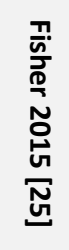 & 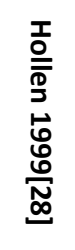 & 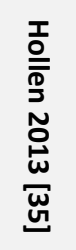 & 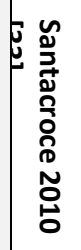 & 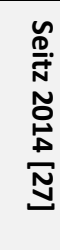 \\
\hline Individual face-face session(s) & $\checkmark$ & $\checkmark$ & $\checkmark$ & $\checkmark$ & & $\checkmark$ & $\checkmark$ & & & & & & $\checkmark$ & $\checkmark$ & $\checkmark$ & & \\
\hline Telephone & & $\checkmark$ & & $\checkmark$ & & & $\checkmark$ & $\checkmark$ & & & & $\checkmark$ & & & & $\checkmark$ & \\
\hline Online/ Internet based & & & & & $\checkmark$ & & & & & $\checkmark$ & & & & & $\checkmark$ & & $\checkmark$ \\
\hline Printed guidebook mailed to participants & & & & & & & & & & & $\checkmark$ & & & & & & \\
\hline \multicolumn{18}{|l|}{ Components } \\
\hline Diary or workbooks & $\checkmark$ & $\checkmark$ & & $\checkmark$ & $\checkmark$ & $\checkmark$ & $\checkmark$ & & & & $\checkmark$ & & & $\checkmark$ & & $\checkmark$ & \\
\hline Pedometer & $\checkmark$ & & & & & & & $\checkmark$ & & & & & & & & & \\
\hline Training session/ instruction & & & & & $\checkmark$ & & & $\checkmark$ & & & & & & & & & \\
\hline Group activities & & & & & & & & $\checkmark$ & & & & & & & & & \\
\hline \multicolumn{18}{|l|}{ Outcome Measures } \\
\hline Quality of life & & & & & & & & $\checkmark$ & & $\checkmark$ & $\checkmark$ & & & & & & \\
\hline Fatigue & $\checkmark$ & & & & & & & & $\checkmark$ & & & & & & & & \\
\hline Physical activity /fitness & $\checkmark$ & & & & & & & $\checkmark$ & $\checkmark$ & $\checkmark$ & $\checkmark$ & & & & & & \\
\hline Anxiety /Depression/Distress & & $\checkmark$ & & & $\checkmark$ & & & & & & $\checkmark$ & & $\checkmark$ & & & $\checkmark$ & $\checkmark$ \\
\hline Feasibility & & & & & & & & $\checkmark$ & & $\checkmark$ & & & $\checkmark$ & & & $\checkmark$ & \\
\hline Decision making/ risk taking / motivation & & & $\checkmark$ & $\checkmark$ & & $\checkmark$ & $\checkmark$ & & & & & $\checkmark$ & $\checkmark$ & $\checkmark$ & $\checkmark$ & $\checkmark$ & \\
\hline
\end{tabular}




\begin{tabular}{|c|c|c|c|c|c|c|c|c|c|c|c|c|c|c|c|c|c|}
\hline \multicolumn{18}{|l|}{ Results (statistically significant) } \\
\hline Improved fatigue & $\checkmark$ & & & & & & & & & & & & & & & & \\
\hline Improved quality of life & & & & & & & & & $\checkmark$ & & & & & & & & \\
\hline Improved decision making & & & & & & & & & & & & & & $\checkmark$ & & & \\
\hline $\begin{array}{l}\text { Improved physical activity/fitness/ } \\
\text { weight loss }\end{array}$ & $\checkmark$ & & & & & & & $\checkmark$ & $\checkmark$ & $\checkmark$ & $\checkmark$ & & & & & & \\
\hline Decreased smoking & & & & & & & & & & & & $\checkmark$ & & & & & \\
\hline Decreased anxiety/ distress/ depression & & $\checkmark$ & & & & & & & & & & & $\checkmark$ & & & & $\checkmark$ \\
\hline Improved body image & & $\checkmark$ & & & & & & & & & & & & & & & \\
\hline Improved diet & & & & & & $\checkmark$ & & & & & & & & & & & \\
\hline Improved knowledge & & $\checkmark$ & & & & & & & & & & & & & & & \\
\hline \multicolumn{18}{|l|}{ Risk of Bias } \\
\hline Random sequence generation & N/A & $\mathrm{U}$ & $\mathrm{N} / \mathrm{A}$ & $u$ & $\mathrm{~L}$ & $\mathrm{U}$ & $\mathrm{U}$ & $\mathrm{N} / \mathrm{A}$ & $\mathrm{N} / \mathrm{A}$ & $\mathrm{L}$ & $\mathrm{L}$ & $U$ & $\mathrm{~N} / \mathrm{A}$ & N/A & L & 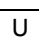 & N/A \\
\hline Allocation concealment & N/A & $\mathrm{U}$ & N/A & $U$ & $\mathrm{~L}$ & $\mathrm{U}$ & $\mathrm{U}$ & N/A & N/A & $u$ & $\mathrm{~L}$ & $\mathrm{H}$ & $\mathrm{N} / \mathrm{A}$ & N/A & $U$ & $u$ & N/A \\
\hline Blinding of participants & N/A & $\mathrm{H}$ & N/A & $\mathrm{H}$ & $\mathrm{H}$ & $\mathrm{H}$ & $\mathrm{H}$ & N/A & N/A & $\mathrm{H}$ & $\mathrm{H}$ & $\mathrm{H}$ & $\mathrm{N} / \mathrm{A}$ & N/A & $\mathrm{H}$ & $\mathrm{H}$ & N/A \\
\hline Blinding of outcome & N/A & $\mathrm{H}$ & $\mathrm{N} / \mathrm{A}$ & $\mathrm{H}$ & $\mathrm{H}$ & $\mathrm{L}$ & $\mathrm{U}$ & N/A & $\mathrm{N} / \mathrm{A}$ & $\mathrm{H}$ & $\mathrm{U}$ & $U$ & $\mathrm{~N} / \mathrm{A}$ & N/A & $\mathrm{H}$ & $\mathrm{H}$ & N/A \\
\hline Incomplete data & $u$ & $\mathrm{H}$ & $\mathrm{H}$ & $\mathrm{L}$ & $\mathrm{H}$ & $\mathrm{U}$ & $u$ & $\mathrm{~L}$ & $\mathrm{~L}$ & $u$ & $\mathrm{~L}$ & $\mathrm{~L}$ & $\mathrm{H}$ & $\mathrm{L}$ & $\mathrm{H}$ & $\mathrm{H}$ & $\mathrm{L}$ \\
\hline Selective outcome reporting & $\mathrm{L}$ & $\mathrm{L}$ & $\mathrm{H}$ & $\mathrm{H}$ & $\mathrm{H}$ & $\mathrm{L}$ & $u$ & $\mathrm{~L}$ & L & $\mathrm{L}$ & $\mathrm{L}$ & $\mathrm{H}$ & $\mathrm{H}$ & $\mathrm{H}$ & $u$ & $\mathrm{H}$ & $\mathrm{L}$ \\
\hline Other sources of bias & $\mathrm{H}$ & $\mathrm{H}$ & $\mathrm{H}$ & $\bar{L}$ & $\bar{L}$ & $\mathrm{~L}$ & $\bar{L}$ & $\bar{L}$ & $\mathrm{H}$ & $\mathrm{H}$ & $\mathrm{H}$ & $\mathrm{H}$ & $\mathrm{H}$ & $\mathrm{H}$ & $\mathrm{H}$ & $\mathrm{H}$ & $\bar{L}$ \\
\hline
\end{tabular}

* Other source of bias include: recruitment (selection bias), measures of exposure, measure of outcome, confounding factors and high lost to follow up.

$\mathrm{L}=$ Low, $\mathrm{U}=$ Unclear, $\mathrm{H}=\mathrm{High}, \mathrm{N} / \mathrm{A}=$ Not applicable as not $\mathrm{RCT}$ 
Conflict of interest statement

None declared 


\section{Highlights}

- $\quad$ Survival rate for adolescents and young adults with cancer are high

- The effects of cancer treatment has life-long consequences on health and well being

- Interventions that optimize health and well-being are required for survivors to reach their

full life potential 